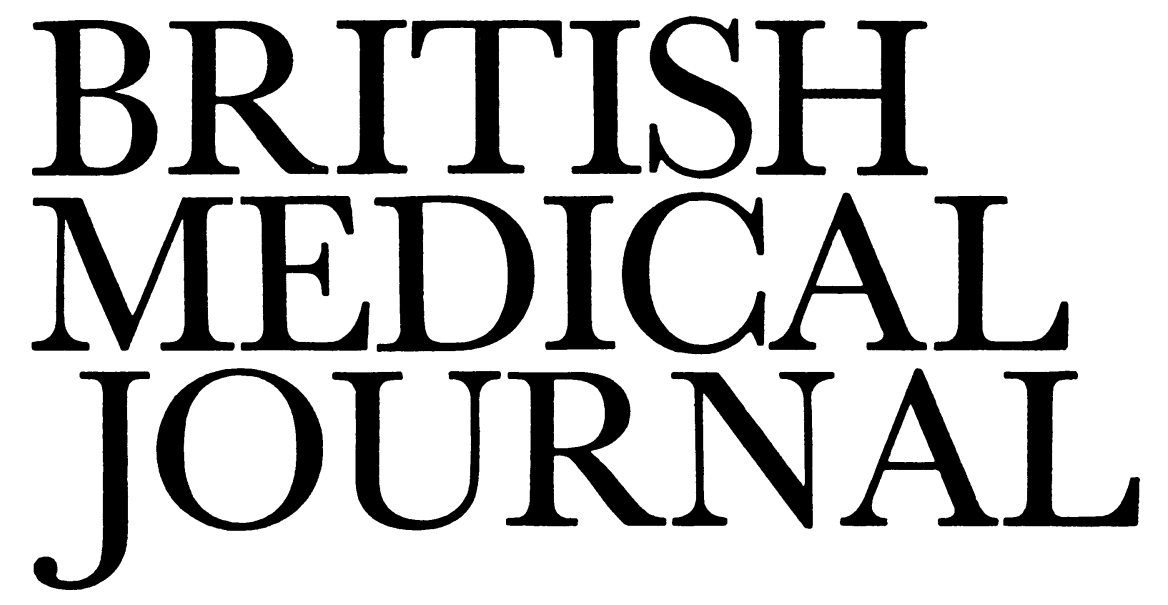

LONDON, SATURDAY 23 AUGUST 1986

\title{
When things go wrong
}

The increased subscription of almost $£ 250$ announced by two medical defence societies will concentrate doctors' minds on better ways of responding when medical treatment goes wrong. The increase was no surprise' and may even be the beginning of a steep ascent into American sized insurance premiums, where $\$ 100000$ is not unknown. Although there are a dozen reasons why "it couldn't happen here" (including the presence of a welfare state and defence societies, who will not settle "nuisance suits," and the absence of juries and contingency fee lawyers), it could-because the basic law is the same.

The immediate causes for the British increases are rises in the numbers of doctors being sued, higher awards in negligence cases, increased legal costs, and more complaints against doctors. In the past 10 years the number of doctors being sued has doubled, and damages have gone as high as $£ 600000 .^{2}$ Million pound awards are presumably just around the corner. In the United States million dollar awards arouse no surprise, and a woman in New York was recently awarded over $\$ 50 \mathrm{~m}$ after treatment for food poisoning had gone wrong. Yet increases in insurance premiums are only part of the problem: worse are the subtle changes that are produced in the way medicine is practised every day. Firm evidence of "defensive medicine" in Britain is hard to find, but the treasurer of the Medical Defence Union seems confident that the rise in the caesarean section rate and investigations may be attributed-at least in part-to fear of litigation. ${ }^{2}$ In the United States the American Medical Association estimates that medical costs related to professional liability, which includes defensive medicine, account for up to a quarter of the amount spent on doctors' services-that is, getting on for $\$ 20$ billion.

Nor do all the problems rest with doctors. If more injured people were compensated as a result of these increases in subscriptions then they might well be acceptable, but all the evidence suggests that only a tiny fraction of those injured in medical accidents ever receive any compensation. We know that proving medical negligence is hard and that many of those who might have a case never even begin an action. Sir Owen Woodhouse, chairman of the royal commission that led to the New Zealand no fault scheme for accident compensation, described the New Zealand tort law system as a "fragmented and capricious response to a social problem that cries out for coordinated and comprehensive treat- ment."'3 His description might just as well be applied to the existing British system, and, indeed, earlier this year the Lord Chancellor's Department described the English system of personal injuries litigation as "inefficient, dilatory and disproportionately expensive."4 (In a trial reported earlier this month a boy who is alleged to have been damaged by negligent care soon after birth is almost 8 years old, and the case still has to go to the House of Lords (p 497). ${ }^{5}$ The four year old organisation Action for the Victims of Medical Accidents has often produced information suggesting that many injured people go uncompensated, ${ }^{6-9}$ and any doctor associated with the media will have a collection of letters from patients who sound as if they have been treated negligently. But what we have not had in Britain is a formal study of how many people are injured by medical treatment (and perhaps the defence societies should consider mounting one). The one study that I know was done in California and showed that just over three million hospital admissions in 1974 led to 140000 injuries, of which 24000 were the result of negligence. ${ }^{10}$ Yet even in that most litigious of communities only 4000 claims were filed, half of which were successful.

Just as in America, there are two possible responses to rising litigation and expenses. Either you can tinker with the present system or sweep it away and try something better. In America, where trial lawyers form perhaps the most powerful lobby in the country, the legislators are busy tinkering. They are trying to limit damages, introduce sliding scales for lawyers' fees, and encourage pretrial reviews, but none of these measures seems to be having much success and have been described by Sir Owen Woodhouse as "frippery."."

Yet a fair bit of tinkering is also going on in Britain. The Law Society wrote last week to the Trade and Industry Secretary to support a request from the Institute of Chartered Accountants for a government inquiry into limiting liability for professional negligence. ${ }^{12}$ Earlier this year the Lord Chancellor's Department suggested several ways for reducing the costs and delay of personal injury litigation. ${ }^{4}$ These include: a shorter period within which proceedings must start; for simpler cases a trial by written evidence only; for longer cases a "hotted up" procedure with a timetable and an early "cards on the table" disclosure system; and for solicitors special qualifications in personal injury work and an obligation to get on with a case. The public's views 
have been sought on the recommendations, and ministerial decisions are expected at the end of the year. These suggestions might speed up cases and reduce costs a little, but it is hard to see that they will do much to reduce the large problems of not enough people being compensated and awards in medical negligence cases increasing so rapidly.

The defence societies' tinkering consists of pleas to doctors to keep good records (because bad records may make a case indefensible); not to overstep their competence; not to overwork or "lack diligence"; and not to treat patients without seeing or examining them. ${ }^{2}$ This is all good advice but does not attack the root of the problem, unless we assume that that root is incompetence, which most doctors would reject.

To stop tinkering and look for a radical solution, we must look again at what the problem is and what happens now. The main problem is that medical accidents are inevitablein perhaps almost $5 \%$ of cases the Californian data suggest. ${ }^{10}$ Action for Victims of Medical Accidents is right to call in its annual report published last week for doctors to try to do more to prevent accidents and to respond more positively after they have happened, but it must recognise that many accidents are inevitable and that most are not the result of negligence. ${ }^{9}$ After the accident patients may want an explanation, justice, an assurance that it will not happen again to somebody else, or compensation. Action for the Victims of Medical Accidents says that in almost three quarters of cases patients simply want an explanation. ${ }^{6}$ Doctors will also want to do their best to ensure that the accident does not recur, and if they think that it has resulted because of another doctor's illness or incompetence they will want help for the doctor. Yet the present system is not very good at satisfying any of these needs.

Explanation may best be provided by the doctor in charge of the case without any resort to lawyers, advisers, or systems, and the current issue of the fournal of the Medical Defence Union makes it clear that to say sorry is not to admit liability. ${ }^{13}$ If that is inadequate then patients should be able to resort to a complaints procedure that is easily accessible and comprehensible and seen to be fair to both doctor and patient. Better systems are also needed to weed out and help the sick and the incompetent doctor. ${ }^{14}$

And compensation is best provided by a no fault system without resort to law. The best system would be one that compensated all injured people regardless of the cause of their injury-be it disease, accident, or negligence. Such a system almost began in Australia. ${ }^{15}{ }^{16} \mathrm{Next}$ best would be a system such as the New Zealand one that compensated all those injured in accidents, ${ }^{16-20}$ and third best would be a Swedish style system that compensated only those injured in medical accidents. ${ }^{21}$

The moral case for such a system seems unanswerable, but as so often the snag is the money. Doctors should not be beaten by this argument. Firstly, there is some sort of no fault system already in so far as an injured person is entitled to free medical treatment and various social security payments. Secondly, the present system is enormously expensive and, worse, inefficient. The Lord Chancellor's Department estimated that for every $£ 100$ awarded in damages in the High Court the costs were between $£ 50$ and $£ 70,{ }^{4}$ and the National Audit Office published a report a few weeks ago saying that $£ 150 \mathrm{~m}$ is being lost through injured people receiving both compensation and social security payments. ${ }^{22}$ Thirdly, the experience from New Zealand and Sweden shows that these systems are not prohibitively expensive. Fourthly, costing the different systems is very complex and those opposed to no fault systems tend to "rig" the cost in their favour. ${ }^{16}$ And, fifthly, there is a strong moral case for sharing out fairly and efficiently whatever funds we do have-rather than letting them be swallowed up by courts and lawyers and go to one lucky person rather than 50 unlucky ones.

Assistant editor, $B M \mathcal{F}$

RICHARD SMITH

Boughton BJ. Medical Defence Union fees. Br Med f 1983;287:364.

Halle HM The cost of medical defence. Foumal of the Medical Defence Union 1986;Summer:3.

3 Royal Commission of Inquiry. Compensation for personal injur in New Zealand. Wellington: New Zealond Govern of Inquiry.

Lord Chancellor's Department. Civil fustice Review. Personal injuries litigation. London: Lord Chancellor's Department, 1986

Anonymous. Law report. Doctor's inexperience no defence to negligence. The Times 1986 Aug 6:4.

6 Action for the Victims of Medical Accidents. Annual report 1983-4. London: AVMA, 1984

7 Simanowitz A. How large is the problem of medical negligence? $\mathrm{Br}$ Med $\mathcal{F}$ 1984;288:1460.

8 Simanowitz A. Negligence claims. Both sides of the coin ... a patient's experience. Fournal of the Medical Defence Union 1986; summer:14-5

9 Action for the Victims of Medical Accidents. Annual repont 1984-85. London: AVMA, 1986.

10 Mills DH. Medical insurance feasibility study. West $\mathcal{f}$ Med 1978;128:360-5.

11 Smith R. Malpractice: a New Zealand solution to an American crisis? Br Med f 1985;291:812-4.

12 Dean M. Damages limit plan backed. Guardian 1986 Aug 12: 2 .

13 Allsopp KM. Saying sorry. Fournal of the Medical Defence Union 1986;summer:2.

14 .

Rhodes $\mathrm{P}$. Incompetence in medical practice. Br Med $\mathcal{F}$ 1986;292:1293-4. ational Committee of

Paver G Compens. Australia. Wellington: Oxford University Press, 1979.

Australia. Wellington: Oxford University Press, 1979.
. Ison TG. Accident compensation. London: Croom Helm, 1980.

17 Ison TG. Accident compensation. London: Croom Helm, 1980.

18 Smith R. The world's best system of compensating injury? Br Med f 1982;284:1243-5.

19 Smith R. Problems with a no fault system of accident compensation. Br Med f 1982;284:1323-5.

20 Smith A. Compensation for medical misadventure and drug injury in the New Zealand no fault system. BrMed f 1986;284:1457-9.

21 Oldertz C. The Swedish patient insurance system. Med Leg $\mathcal{F}_{1984 ; 52: 43-59 .}$

22 National Audit Office. Recovery of social security benefits when damages in tort are awarded. London: HMSO, 1986.

\section{Neurological manifestations of human immunodeficiency virus infection}

New manifestations of infection with human immunodeficiency virus (HIV) are still being recognised, and the most alarming and recent discovery is that the virus may be neurotropic as well as lymphotropic. It is present in the brains of some (if not all) individuals infected with HIV and can cause neurological disease not only in those with the acquired immune deficiency syndrome (AIDS) but also in those who are immunocompetent and may never develop AIDS as currently defined. Such manifestations need to be distinguished from the various neurological opportunistic infections and tumours that affect patients with AIDS. Further new consequences of infection with HIV are also likely to be noticed in the future.

Early evidence for the presence of the virus in the brain was provided by establishing HIV infection in chimpanzees by inoculating brain tissue obtained at necropsy from patients with AIDS.' Shaw et al showed HIV DNA in the brains of five of 15 patients who died with AIDS encephalopathy using Southern blot analysis and also showed viral specific RNA by in situ hybridisation in four of the five cases. $^{2}$ The virus has been isolated from the brains and cerebrospinal fluid of patients with this condition by using reverse transcriptase activity in cell culture supernatants and confirmed by indirect immunofluorescence. ${ }^{34}$ Synthesis of HIV specific IgG has been shown within the blood brain 